\title{
JUSTICE AND ISLAMIC WORK ETHICS A FRAMEWORK FOR LEADERS OF PUBLIC AND PRIVATE ORGANIZATIONS
}

\author{
Mustapha Sidi Attahiru $1 \bowtie$ (iD) \\ ${ }^{1}$ Lecturer, Department of Business Administration, Faculty of Management Sciences, Usmanu Danfodiyo \\ University Sokoto, Nigeria.
}

Received 15 October 2021

Accepted 2 November 2021

Published 30 November 2021

CorrespondingAuthor

Mustapha Sidi Attahiru PhD,

mustattahiru@yahoo.com

DOI

10.29121/granthaalayah.v9.i11.2021 .4397

Funding: This research received no specific grant from any funding agency in the public, commercial, or not-for-profit sectors.

Copyright: (C) 2021 The Author(s). This is an open access article distributed under the terms of the Creative Commons Attribution License, which permits unrestricted use, distribution, and reproduction in any medium, provided the original author and source are credited.

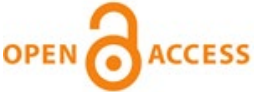

\section{ABSTRACT}

Immorality in the public/private service has been a great concern to various governments and researchers throughout the world because of its complexity. Despite all the existing laws, rules and regulations pertaining to the public service, the policy makers have failed to arrest the situation that is multiplying day by day. This may not be unconnected with the neglect of religious ethics that control the heart of an individual as it affects the public service. Islam provides comprehensive ethical guidelines for the running of public service which can be achieved through Islamic justice and fairness. To have faithful leaders, it is of great importance for the policy makers to ensure the manifestation of religious ethics and justice in the public service through the public awareness. Using proposed methodology this paper presents a conceptual review of the leader's work ethics based on Islamic perspectives as well as its application in modern business toward sustaining the performance of the public and private organizations. This research is significant as there is a lack of Islamic code of ethics that guides the public and private organizations effectively. There is need for empirical test in the future as this research is conceptual in nature.

Keywords: Justice, Islamic Work Ethics, Public Service

\section{INTRODUCTION}

In Islam, work is the instrument for achieving success, self-respect, wellbeing of individuals and organisations Elamin and Tlaiss (2015). Public service of any country can only be well-organized when its environment is efficiently free of all types of unethical practices as they negatively affect the performance of workers and organizations Arowolo (2012). Muslims in the world encourages Islamic principles in their workplace because they provide the organisation some guidelines on how to maintain quality and successfully improve administrative practices Aldulaimi (2016). Many countries were richly blessed with intellectuals in almost every sector of human development as well as material resources that can be used for national development. Nevertheless, inefficient utilization of these resources due to lack of leadership style and non-determination by the subordinates hindered the development of those countries for decades Imhonopi and Moses (2013). Also, poor working conditions, politicisation of service, injustice in recruitment and promotion, abuse of office, bribe for award of contracts, lateness, absenteeism, fraudulent staff, insubordination, idleness, lack of commitment to work among others are some of the contributors for unethical 
circumstances and practices in most of the public sectors Anyim et al. (2013).

Despite all the measures taken by various governments to arrest the situation of ethical failure in the public and private service of their countries, the problem still persist Arowolo (2012). This is attributed to the long colonisation of some countries which weakens the communication and religious teachings among the people and that resulted in non-application of religious values and principles in the public service of those countries ElKaleh and Samier (2013). Another factor is the neglect of Islamic work ethics as it provides economic as well as moral and social dimensions. This is because work is not an end in itself, but as a means to foster personal growth and social relations. However, work in Islam is situated in the core of the faith and is seen as an integral part in life, and that influenced Muslims to offer unique perspectives on work and also formulate specific conceptualization of work ethics which at the end will strengthen organizational commitment and continuity Ali and Al-Owaihan (2008). Furthermore, Islam covers all aspects of human life; Islam is not only a doctrine of worship but also an integrated system that governs all rules, obligations, values, manners and practices to ensure the integrity and justice between human beings Ali ARAH et al. (2018). Thus, Qur'an and Hadith provide fundamental ethical values for leaders as solution to the aforementioned problems.

In this regard, using proposed methodology this study highlights the position of Islam on the aforementioned issues affecting the work ethics in the public service. This paper is divided into four sections. The first section is the introduction, section two is the literature review, while section three is the hypothesis development and section four comprise the recommendations and conclusion.

\subsection{SIGNIFICANCE OF THE STUDY}

This paper provides a framework for the leaders of public and private sectors based on Islamic perspectives that is rooted in the Holy Qur'an and Hadith of Holy Prophet Muhammad Peace be upon him (PBUH) This is with a view to eliminate nepotism, injustice and other unethical behaviours from affairs of leadership and ensure the maintenance of qualitative administrative practices.

\section{LITERATURE REVIEW \\ 2.1. ISLAMIC WORK ETHICS}

Ethics according to Velasquez (2014) is the discipline that examines the moral standards of an individual or a society to evaluate their reasonableness and their implications for one's life. Beekun (1997) defines ethics as moral principles that distinguish what is right from what is wrong. Aldulaimi (2016) said that ethics from the Islamic perspective is seen as a conduct that refers to attributes, manners and actions performed by certain individuals to attain a high-quality life. Thus, Suahib (2009) argued that Islamic ethics covers doing what is right and avoiding what is wrong and therefore is not only limited to business transactions but covers every aspect of human's life. Accordingly, work ethics is the application of moral principles to the behaviour of individuals within organisations Alhyasat (2012). Islamic work ethics refers to being oriented toward business earnings and is a quality essential to form a balance in the social and individual life of a person Ali (2001), Ali (1992) , to discharge his responsibilities toward Allah Ali and Al-Kazemi (2007). 


\subsection{JUSTICE}

According to Rawls (2005) "The primary objective of justice is the basic structure of society or more exactly, the way in which the major social institutions distribute fundamental rights and duties and determine the division of advantages from social co'operation". Sandel (2007) asserted that a society is said to be just when it effectively distributes its income and wealth, powers and opportunities, duties and rights without denying any person what is due to him. The word "justice refer to the administration of law according to prescribed and accepted principles" Bello (2012). It is also seen as putting everything into the rightful place at the appropriate time, in the appropriate way and level without any extravagance, misery, excess or delay as well as giving everyone their rightful due Aljahiz (1989), Askari and Mirakhor (2020). Justice is very close to equality because it creates a state of balance in the allocation of rights and duties (IslamReligion.com, 2008). Thus, justice is encouraged by Islam in all cases that affects fellow beings without any discrimination by offering everyone what belongs to him and abstaining from harming him Al Jaza'iri (2000). To maintain a proper standard of justice, it is necessary that reward or remuneration of good should in no case be less than what a person has earned, and that on the other hand the penalty for a wrong should not exceed the wrong or transgression committed Attahiru (2018). A contravention of either of these principles would result to injustice.

Ibn Al-Qayyim (2007) said; Allah (SWT) has made it clear in His laws that the objective of shariah is to establish fairness and justice among the people. Therefore, whatever way leads to justice is part of Islam and it can never be opposed. According to Khadduri (2002), the scales of justice considerably differs from place to place and each scale is determined by the society in accordance with the order of that society. Nevertheless, no matter the difference in the scales, they all appear to have common elements which may be categorically divided into two. The first category is found in that society who feels that they can determine and establish their own laws base on their agreement. This type of justice has been admitted being imperfect and the affected society is always trying to refine and improve it by continuous process of social change. The second category is in a society which assumes that human being is basically weak and is incapable of effectively establishing his own laws. In such a society, a divine authority is call upon to provide the fundamental principles of the public order to establish a standard justice. This divine justice is what is known as Islamic justice Khadduri (2002).

\subsection{PUBLIC SERVICE}

Public service is a department or body of government that is responsible for the planning and implementation of policies of government Arowolo (2012). Also Omisore (2015) described the public service as a manifestation of the public service, line ministries and Extra-ministerial agencies that comprises of states and national assemblies, the judiciary, the police, the Armed forces, and other security agencies, the paramilitary services, agencies and parastatals.

The public service plays an important role in the policy of government that includes advising the government technically and professionally based on expertise, knowledge and long service experience, development of programmes and options for the execution of government projects in accordance with the availability of resources, monitoring and evaluation of programmes and on-going projects as well as ensuring the implementation of all government policies for the achievement of set goals and objectives among others Omisore (2015). 


\subsection{JUSTICE AND ISLAMIC WORK ETHICS IN PUBLIC SERVICE}

Justice refers to the rendering of trusts where it is due, including upholding the commandment of Allah SWT in the form of commands, as well as prohibition Salin (2020). Islamic places justice as the key point of morality in any transaction otherwise the human society will destined toward destruction and decline Wulandari et al. (2016). This is supported by Al-Qur'an: "Be just, that is closest to awareness of God (Allah)” (Al-Qur'an, 5:8). Also, in Al-Qur'an (16:90): “God enjoins justice and doing good". This is the message brought to this world by each and every Messenger of God with a view to maintain balance in the society. Al-Qur'an speaks;

"Indeed, we have sent Our Messengers with clear proofs, and revealed with them the Scripture and the balance (justice) that mankind may keep up justice." (Al-Qur'an, $57: 25)$

Justice therefore is decreed in all aspects and to all categories of mankind irrespective of their religion, tribe and status because it is the only way of achieving success not only in the government business but all activities of life. Al-Qur'an says:

"O you who believed, be persistently standing firm for Allah, witness in justice, and do not let the hatred of a people prevent you from being just. Be just; that is nearer to righteousness. And fear Allah; indeed, Allah is Acquainted with what you do" (AlQur'an, 5:8).

The Al-Qur'an says further:

"O you who believe, be persistently standing firm in justice, witness for Allah, even if it be against yourselves or parents and relatives. Whether one is rich or poor, Allah is more worthy of both". (Al-Qur'an, 4:135)

Thus, in any transaction, whether public or private, a Muslim is expected to be just in his conducts, bearing in mind that all transactions are being witness by God Himself. Al-Qur'an says:

"Nor you (mankind) do any deed (good or evil), but We are Witness thereof, when you are doing it. And nothing is hidden from your Lord (so much as) the weight of an atom (or small ant) on the earth or in the heaven. Not what is less than that or what is greater than that but is (written) in a Clear Record." (Al-Qur'an, 10:61)

Amilin et al. (2018) asserted that understanding the relationship between work ethics and organizational justice is crucial in mitigating the issues of employee's performance. In this regard, those who apply the concept of justice in the public service will be successful both here and hereafter.

\subsection{CONCEPTUAL FRAMEWORK}

Having conducted the groundwork for this study as expressed in the review of related literature about the study's variables in this chapter the research framework was developed. This is very important because it can indicate the direction of the relationship among the variables and provide a foundation for hypothesis

development. Figure 1.0 below is the conceptual framework for this study, the dependent variable is the Islamic work ethics and Justice is the independent variable. 


\begin{tabular}{|l|l|}
\hline Justice & $\begin{array}{c}\text { Islamic Work } \\
\text { Ethics in Public } \\
\text { Service }\end{array}$ \\
\cline { 2 - 3 }
\end{tabular}

Figure 1 Conceptual Framework

Islam completely rejects injustice in public service such as favouritism and cronyism in hiring and firing of employees, fraud, monopoly, exploitation and at the same time encourages prosperity through the proper use of Allah's resources provided for mankind Muhammad et al. (2012). Among the duties of any person entrusted with a leadership position is to oversee the affairs of his domain, to apply the religious teachings among his people, to establish justice throughout his realm and to provide for the needs of his people Mujahid (2012). According to Sultan Muhammad Bello of the Sokoto Caliphate, any person given a trial of leadership in the public service should strive to play it safely since he is going to give the account of his leadership that comprises his actions, words and affairs before Allah (SWT) Yusuf (2013)

The Prophet (PBUH) said: "Indeed, the most beloved of people to Allah on the Day of Judgement, and the nearest to Him in status is the just leader. And the most hated of people to Allah and the furthest from Him in status is the oppressive leader" (AtTirmidhi:1329)

When Abubakar As-Siddeeq (May Allah be pleased with him) was appointed the first caliph of Islam, he applied the principle of equality. Mujahid (2012) quoted Abubakar when he addressed the companions (May Allah be pleased with them) as follows:

"O people, I have indeed been appointed overyou, though I am not the best among you. If I do well, then help me; and if I act wrongly then correct me... Truthfulness is synonymous with fulfilling the trust, and lying is tantamount to treachery. The weak among you is deemed strong by me, until I return to them that which is rightfully theirs Insha Allah (Allah willimg). And the strong among you is deemed weak by me until I take from them what is rightfully (someone else's), insha Allah."

Also, Syed Agil et al. (2007) quoted the second Caliph of Islam Umar Al - Khatab when he addressed his officials in a public meeting as follows:

"Remember, I have not appointed you as commanders and tyrants over the people. I have sent you as leaders instead, so that people may follow your example. Give the Muslims their rights"

Islam encourages equal right in the use of Government facilities and prohibits unequal distribution of Government wealth and favouritism. Prophet Muhammad (PBUH) indicated that it is one of the terrible things that will happen prior to the day of judgement (Sunan At-Tirmidhi: 2211 ) Sheikh Abdullahi Bn Fodio reported that, a leader should give everybody the right he owes even if that right will be against the leader or some persons among his subjects Luwa (2013). Also, Al-Qur'an says;

"And be fair: for Allah loves those who are fair (and just)" (Al-Qur'an, 49:9)

Sallabi (2010) reported that, the fourth Caliph of Islam Ali ibn Abi Talib was known to be following the general principle of equality confirmed by Islam in his administration. Al-Qur'an says: 
O mankind! We have created you from a male and a female, and made you into nations and tribes, that you may know one another. Verily, the most honourable of you with Allah is that [believer] who has At-Taqwa [i.e., he is one of the Muttaqoon (the pious)]. Verily, Allah is All-Knowing, All-Aware. (Qur'an 49: 13)

Ali's implementation of this principle is the best model. He gave to the people equally without allowing himself to take anything from this wealth except as much as he gave to other people. Ali also gave stipends to his opponents just as he gave to others, and He did not give precedence to a nobleman over a commoner or to an Arab over a non-Arab Sallabi (2010)

Ali (2016) said that, the important condition of Islam is that there should be perfect fairness and justice and respect for the highest principles, because Islam takes account of every just and legitimate interest without separating spiritual from temporal matters.

\section{Recruitment}

In terms of appointment and recruitment, only those who are competent and honest will be appointed or recruited as highlighted by the Al-Qur'an: 28:26)

"Indeed, the best one you can hire is the strong and the trustworthy." (Al-Qur'an,

Favouritism and recruitment of unqualified personnel or appointment of incompetent people on key position of governance were strongly condemned by Islam, and Prophet (PBUH) described it as one of the terrible things that will happen before the day of judgement. The Prophet said,

"When the power or authority is given to those who do not deserve it then wait for the (last) Hour"(Sahih Al-Bukhari: 59)

Sultan Muhammad Bello emphasised that, it is incumbent on a leader to exert his best in selecting the righteous workers, he should select only those people with determination, honest and trustworthy. Their appointment should also be based on piety not desire Nabingo (2013). Furthermore, contract for employment which must be respected should be made clear and agreed upon between employer and employee. Prophet (PBUH) said:

"Employer must declare the wages to worker before the worker embark on the required work" Khan (1992).

Also, Allah Said "O you who believe fulfill your contract" (Qur'an, 5:1) "Fulfill your agreement, surely, you will be questioned about it" (Qur'an, 17:34)

Prophet Mohammed (PBUH) said: "Muslim must abide by their agreement" $\mathrm{Al}$ Tirmidi: 1352)

\section{Payment of salary and wages to employees}

Also, the timely payment of workers salary without unnecessary delay is encouraged by Islam because of the sayings of Prophet Muhammad (PBUH):

"Give the wages of employee before his sweat dry". (Ibn Majah, Hadith no. 2468)

"Delay in paying debts by a wealthy man is Injustice" (Sahih Al-Bukhari 2287; Muslim 1564)

Payment of salaries and wages to employees should also be as agreed. Unlawful deduction is not permissible in Islam. Allah Said: "Do not withhold from the people the things that are their due" (Qur'an,7:85) 
Prophet said, "Allah (SWT) will be an opponent to anyone who employs a labourer and takes full work from him but does not pay him for his labour.'" (Sahih AlBukhari: 2270)

Sheikh Abdullahi Bn Fodio highlighted that a good leader must have an information pertaining his workers salary, he should pay them what is due to them according to the level of their work at the appropriate time Luwa (2013). Workers that exhibit morality in their work should be considered suitable for additional responsibilities and promotion because of the impact of their action to the organisation and the society. They should be rewarded and encouraged to report any unethical behaviour within the organisation. Similarly, those who unethically violate the rules should be accordingly punished as indicated by Holy Al-Qur'an:

"As for one who wrongs, we will punish him. Then he will be returned to his Lord, and He will punish him with a terrible punishment. But as for one who believes and does righteousness, he will have a reward of the best, and we will speak to him from our command with ease."'”. (Al-Qur'an, 18: 87-88)

\section{Prohibition of discrimination}

Discrimination when it comes to punishment is not allowed in Islam because of its negative impact to the service as well as the society in general. Al-Qur'an says:

"So, judge between the people in truth and do not follow [your own] desire, as it will lead you astray from the way of Allah." (Al-Qur'an, 38:26)

In another verse, Allah (SWT) says: And when you speak [i.e., testify], be just, even if [it concerns] a near relative. And the covenant of Allah fulfill. This has He instructed you that you may remember." (Al-Qur'an 6:152)

In the Hadith narrated by Aisha (RA), Prophet (PBUH) says: "0 people, those who came before you were doomed because if a nobleman among them stole, they let him off, but if a lowly person stole, they carried out the punishment on him"(Sahih Muslim: 1688)

Appropriate steps should be taken when it comes to disciplinary action. Sheikh Abdullahi Ibn Fodio expressed that, the officer who committed an offence should first be queried and be allowed to answer the query given to him before taking any disciplinary action against him. Sheikh Abdullahi Ibn Fodio emphasised that any punishment must be within the circle of the law. Justice should also be done when taking any action because Allah (SWT) is watching Luwa (2013).

\section{Bribery and corruption}

Islam prohibits all forms of bribery. This involves giving or taking bribe by all the parties concern. Al-Qur'an, says:

"And do not consume one another's wealth unjustly or send it [in bribery] to the rulers in order that [they might aid] you [to] consume a portion of the wealth of the people in sin, while you know [it is unlawful]"(Al-Qur'an, 2:188). It was also narrated that 'Abdullãh bin 'Amr said: "The Messenger of Allah cursed the one who gives a bribe and the one who takes it."(Sunan Abu Dawud:3580)

In addition, corruption in the public service is seriously condemned by Islam. Corruption refers to a form of requesting or accepting, directly or indirectly of any benefit that include monetary goods, favour, gift, promises or advantage by any other persons, public officials or entity in exchange for any act or omission in the performance, of his/her public functions Smith (2007). Adiyy bin 'Umairah Al-Kindi narrated that the Messenger of Allah (BUH) said: 
"0 people, whoever among you is appointed by us to do some work, and he conceals (for himself) a needle or less from us, it will be a yoke of iron on his neck that he will bring on the Day of Resurrection." (Sunan Abu Dawud: 3581)

Smith (2007) highlighted that; some people are "culturally active partners of corruption". For a person to benefit from any service, he must have an affiliation with someone in authority or pay extra fees. Some people even took it as part of their culture to give bribe for all their entitlements to the extent that they beg the officers to receive a bribe from them. In this regard, Islam discourages any gift to the public officer that relates to his work in whatever form. Prophet (PBUH) in his response to the employee who was given a gift during his official assignment:

"Why doesn't he sit in the house of his father or the house of his mother and see if he is given anything or not. By the One in Whose Hand is the soul of Muhammad! None of you gets anything from it (unlawfully), but he will bring it on the Day of Resurrection, carrying it on his shoulders, even if it is a groaning camel, a lowing cow or a bleating sheep.' Then he raised his arms until we saw the whiteness of his armpits, then he said: '0 Allah, have I conveyed (the message)?' two times."(Sahih Muslim: 1832)

\section{Trustworthiness}

Islam encourages leaders of public offices in keeping secrets and honour of the government and delivers the services entrusted in them at whatever capacity as agreed in the condition of service. Al-Qur'an decrees in more than one verse:

"O you who believe Fulfill (your) obligations" (Al-Qur'an, 5:1). This indicates that trustworthiness is very essential to a Muslim's faith, especially those who occupies the leadership positions Ali (2017). Islam has made trustworthiness obligatory for all Muslims in their relationship with Allah (S.W.T) and their business dealings with others Ali (2017). Being trustworthy entails being honest in business dealings, punctual (regarding regularity and timeliness), keeping promises and honouring commitments. The Al-Qur'an mentions:

"Those who faithfully observe their trusts and their covenants. And who (strictly) guard their prayers. These will be the heirs. Who will inherit Paradise: they will dwell therein (for ever)" (Al-Qur'an, 23:8-11)

Ibn Kathir (2015) highlighted that good Muslims will not break any promise or betray any trust between them. Also, they are the keepers of their trust and promises between them and Allah and between them and their fellow human beings Al-Mahalli et al. (2007). This includes trust in financial matters, secrets and promises between them (As-Sa'di, 2014). This is because any promise in whatever form is deemed a trust (Al-Qurtubi, 2013).

\section{Good working condition}

Provision of favourable working atmosphere to the employees by the employer is necessary from the Islamic view. Prophet (PBUH) has cursed the leaders who are not kind to their subordinates. The Hadith narrated by Aisha (RA); the Messenger of Allah has said:

"Allah, whoever attains any position of authority among my Ummah and is harsh towards them, be harsh towards him, and whoever attains any position of authority among my Ummah and is kind towards them, be kind towards him" (Sahih Muslim, 1828) 
Thus, the employer is expected to make the work easy for the employee by provide training, tools and equipment as needed. This will enhance the performance of the employees and also attract reward in the life after death.

\section{Punctuality}

Also, Islam commands the leaders and subordinates in punctuality to duty which comprises reporting to the working place at the stipulated time and closing at the agreed time without abscondment. This is because punctuality is an agreement between the employer and employee, and Al-Qur'an decrees:

"O you who believe Fulfill (your) obligations" (Al-Qur'an, 5:1).

Also. non-punctuality to work means reduction in weight and measure of the working hours and the responsibilities given to the worker by his employer. Therefore, Al-Qur'an states:

"And observe the weight with equity and do not make the balance deficient." (AlQur'an 55:9).

"So, give full measure and full weight and wrong not men in their things, and do not mischief on the earth after it has been set in order, that will be better for you if you are believers." (Al-Qur'an 7:85)

And those who are not punctual to their working place and also give less service to their employer and at the same time claim full payment for the services they did not render from their employers will face the consequences of their action in the hereafter. Al-Qur'an decrees:

"Woe to Al-mutaffifun (those who give less in measure and weight). Those who when they have to receive by measure from men, demand full measure, and when they have to give by measure or weight to (other) men, give less than due. Do they not think that they will be resurrected (for reckoning), on a great day? The day when (all) mankind will stand before the Lord of the Alamin (mankind, jinn and all that exists)?" (Al-Qur'an 83:1-6)

\section{Honesty}

Islam orders all people to be honest and also speak the truth always, including the running of affairs of public offices. In this regard, Al-Qur'an (5:119) decrees that on the Day of Judgement, Allah (S.W.T) will say to all people:

"Allah will say: "This is a day on which the truthful will profit from their truth: theirs are gardens, with rivers flowing beneath, - their eternal Home: Allah wellpleased with them, and they with Allah. That is the great salvation, (the fulfilment of all desires)".

The above verse, according to Jalil et al. (2010), clearly states the reward that Allah (S.W.T) will give to the truthful and honest public officer. In addition, trust is part of the culture of a true leader that is intolerant of distrust in all its forms. Islam emphasises trust in all dealings. Ibn Kathir (2015) commented that a Muslim is required to always speak the truth and adhere to it in order to become among the people of truth and also be saved from devastation. Trust is what makes the religion and faith of a leader complete; it also brings peace of mind and blessings in his business, apart from saving a leader from unwanted calamities Al Jaza'iri (2000). The influence of trust is displayed in the Prophetic tradition reported by Sahih AlBukhari: 6094:

"Truthfulness leads to Al-Birr (piety, righteousness, and every act of obedience to Allah), and Al-Birr Leads to Paradise. And a man keeps on telling the truth until he becomes a Siddiq (honest person). Falsehood leads to Al-fujur (wickedness, evil-doing), 
and Al-fujur leads to the (Hell) fire. And a man keeps on telling lies till he is written as a liar before Allah."

In the light of the above, a Muslim is expected to control all his actions and words at his working place to obtain double reward (in this world and hereafter). Therefore, justice influences the Muslims behaviour on IWE. From the above discussion, the following hypothesis is developed.

$H 1=$ There is significant relationship between Islamic justice and work ethics in the public service

\section{CONCLUSIONS AND RECOMMENDATIONS}

This paper discussed the application of the Islamic character of justice into the behaviour of leaders of public and private organizations. The character of justice is what makes the leader to behave ethically in his activities as a leader. Important issues that strengthen the relationship between employer and employees were discussed. These include: recruitment and appointments payment of salary and wages, promotion and discipline, trustworthiness and honesty among others. Public office holders will only be seeing as good leaders when justice is maintained in their domain. Furthermore, leaders must speak and deliver only the truth without any intention of exploiting their people. In exercising ethical conduct, leaders should be trustworthy in keeping the secret as well as the remaining responsibilities entrusted on them. As this paper is conceptual in nature, it is recommended that future research could be conducted empirically to test the relationship of Islamic justice and aforementioned item earlier discussed in this paper.

\section{REFERENCES}

Al Jaza'iri AJ. (2000) Minhaj Al Muslim. Fourth. Madina K.S.A: Darussalam Printing and Distribution. 448 p.

Al-Hilali MT-D, Khan MM. (2014) The noble Qur'an English translation of the meanings and commentary. Madina K.S.A: King Fahd Complex for the printing of the Holy Qur'an. $978 \mathrm{p}$.

Al-Khattab N. (2007) English translation of Sahih Muslim. First. Khattab H, editor. Riyad: Darussalam.

Al-Mahalli J al-D, Al-Suyuti J al-D. Tafsir al-Jalalayn (2007) [Internet]. First. Bin Talal $\mathrm{G}$ bin M, editor. Amman, Jordan: Royal Aal al-Bayt Institute for Islamic Thought; [cited 2016 Sep 17]. 786 p.

Aldulaimi SH. (2016) Fundamental Islamic perspective of work ethics. J Islam Account Bus Res.7(1):59-76. Retrieved from https://doi.org/10.1108/JIABR-02-2014-0006

Alhyasat KM. (2012) The role of Islamic work ethics in developing organizational citizenship behavior at the Jordanian Press Foundations. J Islam Mark. 3(2):139-54. Retrieved from https://doi.org/10.1108/17590831211232555

Ali A. (2001) Scaling an Islamic work ethic. J Soc Psychol.128(5):575-83. Retrieved from https://doi.org/10.1080/00224545.1988.9922911

Ali AJ, Al-Kazemi AA. (2007) Islamic work ethic in Kuwait. Cross Cult Manag An Int J. 14(2):93-104. Retrieved from https://doi.org/10.1108/13527600710745714 

Ali AJ, Al-Owaihan A. (2008) Islamic work ethic: a critical review. Cross Cult Manag An Int J. 15(1):5-19. Retrieved from https://doi.org/10.1108/13527600810848791

Ali AJ. (1992) The Islamic work ethic in Arabia. J Psychol.126(5):507-19. Retrieved from https://doi.org/10.1080/00223980.1992.10543384

Ali ARAH, Noordin K Bin, Achour M. (2018) The Islamic approach of obligations in mutual relations between employee and employer. Int J Ethics Syst. 34(3):338-51. Retrieved from https://doi.org/10.1108/IJOES-12-20170227

Ali AY. (2012) The Meaning of The Holy Qur'an: Text, Translation and Commentary. New. Kuala Lumpur Malaysia: Islamic Book Trust. 1520 p.

Ali SN. (2017) Building trust in Islamic finance products and services. Soc Bus Rev [Internet].12(3):356-72. Retrieved from https://doi.org/10.1108/SBR-032017-0017

Aljahiz AUA bin B. Tahzib Al Akhlaq. (1989) First. Benzine: Dar As Sahaba Lit Turaath. 70 p.

Amilin A, Ismail T, Astuti S, Reskino, Mulazid AS. (2018) Islamic work ethics and organizational justice implementation in reaching accountants' job satisfaction. Acad Account Financ Stud J.22(1).

Anyim FC, Ufodiama NM, Olusanya OA. (2013) Ethics in nigeria public sector: the HR practitioners' perspectives. Eur J Bus Soc Sci.2(8):132-43.

Arowolo D. (2012) Ethics, Motivation and Performance in Nigeria ' s Public Service.2(5):37-43.

Askari H, Mirakhor A. (2020) Conceptions of Justice from Islam to the Present. Switzerland: Palgrave Macmillan. 304 p. Retrieved from https://doi.org/10.1007/978-3-030-16084-5

Attahiru MS. (2018) Religiosity, Islamic Culture and Islamic Business Ethics Practice in Sokoto Business Dealings: A Moderating Role of Hisbah Principles. Universiti Utara Malaysia.

Beekun RI. (1997) Islamic Business Ethics. USA: The International Institute of $\begin{array}{lllll}\text { Islamic } & \text { Thought, } & 88 & \text { p. } & \text { Retrieved from }\end{array}$ https://doi.org/10.2307/j.ctvk8w1zv

Bello SAA. (2012) The Role of Justice in Islam. SSRN 2183623, 2012. Kuala Lumpur Malaysia. p. 1-20. Retrieved from https://doi.org/10.2139/ssrn.2183623

ElKaleh E, Samier EA. (2013) The Ethics of Islamic Leadership: A Cross-Cultural Approach for Public Administration. Adm Cult.14(2):188-211.

Elamin AM, Tlaiss HA. (2015) Exploring the relationship between organizational citizenship behavior and organizational justice in the Islamic Saudi Arabian context. Empl Relations [Internet]. [cited 2017 Dec 21];37(1):2-29. Retrieved from https://doi.org/10.1108/ER-03-2014-0033

Ibn Al-Qayyim A. (2007) Al Turuk Al Hukmiyya. Jeddah: Dar Alim Al Fawaa'id. 1213 p.

Imhonopi D, Moses UU. (2013) Leadership crisis and corruption in the Nigerian public sector: An Albatross of National Development. An online J African Educ Res Netw.13(1):78-87.

IslamReligion.com. (2008) Justice in Islam [Internet]. The Religion of Islam.

Jalil A, Azam F, Rahman MK. (2010) Implementation Mechanism of Ethics in Business Organizations. Int Bus Res [Internet].3(4):145-55. Retrieved from https://doi.org/10.5539/ibr.v3n4p145 
Khadduri M. (2002) The Islamic Conception of Justice. Vol. 20, Middle East Studies Association of North America ( MESA ). Baltimore, Maryland, United States: The Johns Hopkins University Press. p. 135-41.

Khallyl A. (2007) The English Translation of Jami' At-Tirmidhi. First. Khaliyl A, editor. Riyadh Saudi Arabia: Darussalam.

Khan MM. (1997) Sahih Al-Bukhari Arabic-English. Khan MM, editor. Riyadh Saudi Arabia: Darussalam.

Khan MS. (1992) Islam and The Economic System. Vol. 2, Review of Islamic Economics. 1-29 p.

Luwa AB. (2013) Selected writings of Sheikh Abdullahi Bn Fodiyo (A guide to the Sultan and other brothers). Musa S, editor. Gusau, Nigeria: Iqra' publishing house, Gada-biyui. 131-180 p.

Muhammad MZ, Yusof MF, Amin H, Chowdhury MSR. (2012) Islamic Business Ethics in Small and Medium Enterprises (SMEs): An analysis. In: 3rd International Conference on Business and Economic Research (3rd ICBER 2012) Proceedings [Internet]. Bandung, Indonesia; [cited 2016 Oct 26].

Mujahid A-M. (2012) Golden Stories of Abubakar As-Siddeeq. Riyadh: Dar-us-Salam Publications.

Nabingo YI. (2013) Selected writings of Sultan Muhammad Bello (Relief for the people). Musa S, editor. Gusau, Nigeria: Iqra' publishing house, Gada-biyui. 273-280 p.

Omisore BO. (2015) Work ethics, values, attitudes and performance in the nigerian public service: issues, challenges and the way forward. J Public Adm Gov.5(1):157-72. Retrieved from https://doi.org/10.5296/jpag.v5i1.7367

Qadhi Y. (2008) English translation of Sunan Abu Dawud. First. Riyadh Saudi Arabia: Darussalam.

Rawls J. (2005) A Theory of Justice. United States of America: Presidend and Fellows of Harvard College. 624 p.

Salin ASAP, (2020) Manan SKA, Kamaluddin N. Ethical framework for directors learning from the prophet. Int J Law Manag. 62(2):171-91. Retrieved from https://doi.org/10.1108/IJLMA-04-2018-0075

Sallabi AM. ALI ibn Abi Talib (2010) [Internet]. International Islamic Publishing House. 629 p.

Sandel MJ. (2007) Justice What's the right thing to do? New York. 173 p.

Smith DJ. (2007) A culture of Corruption, Everyday Deception and Popular Discontent in Nigeria. United Kingdom: Princeton University Press. 353 p. Retrieved from https://doi.org/10.1515/9781400837229

Suahib AQ. (2009) Business Ethics in Islamic and Economic Perspective.

Syed Agil SO, Jasin D, Pa'wan F. (2007) Nine Islamic management practices and habits in Islamic history: Lessons for Managers and Leaders. Unitar EJournal. 3(2):42-59.

Translation SI. The Qur ' ān [Internet]. Retrieved from http://www.islamwb.com/books/Qur'an-Saheeh-International-EnglishTranslation.pdf

Velasquez MG. (2014) Business Ethics Concepts and Cases. Seventh Ed. United State of America: Pearson Education Limited.

Wulandari P, Putri NIS, Kassim S, Sulung LA. (2016) Contract agreement model for murabahah financing in Indonesia Islamic banking. Int J Islam Middle East 


$\begin{array}{llll}\text { Financ } & \text { Manag. } & 9(2): 190-204 . & \text { Retrieved }\end{array}$
https://doi.org/10.1108/IMEFM-01-2015-0001

Yusuf MK. (2013) Selected writings of Sultan Muhammadu Bello (Principles of leadership). A.B Y, editor. Gusau, Nigeria: Iqra' publishing house, Gada-biyui. 259-269 p. 